\title{
Working
}

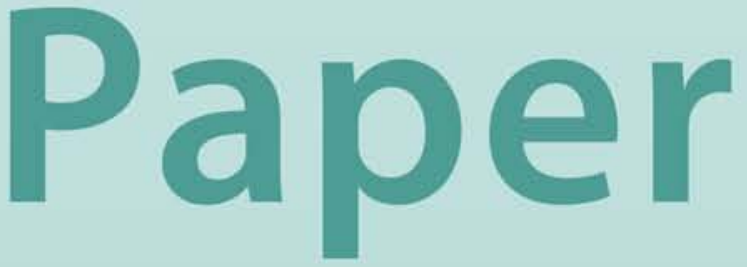




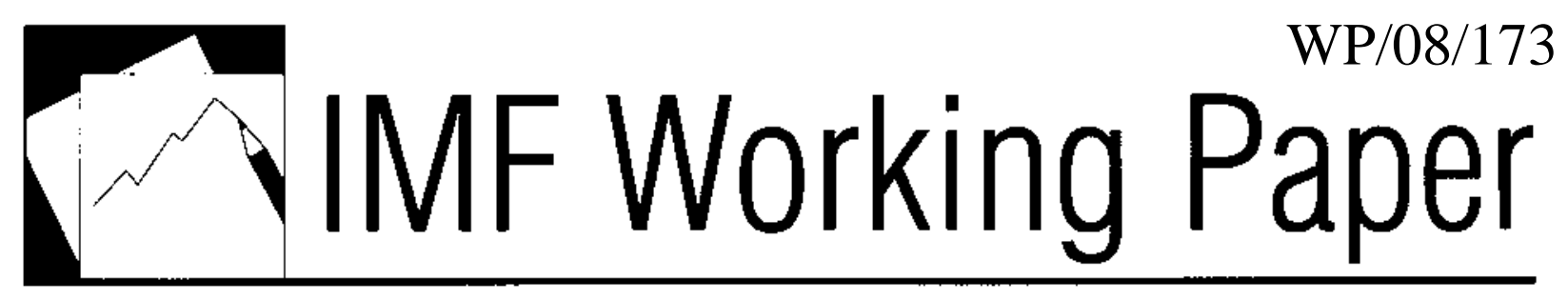

\section{Determinants of Foreign Currency Borrowing in the New Member States of the EU}

Christoph B. Rosenberg and

Marcel Tirpák 


\title{
IMF Working Paper
}

European Department

\section{Determinants of Foreign Currency Borrowing in the New Member States of the EU}

\section{Prepared by Christoph B. Rosenberg and Marcel Tirpák ${ }^{1}$}

Authorized for distribution by Christoph B. Rosenberg

July 2008

\begin{abstract}

\section{This Working Paper should not be reported as representing the views of the IMF.}

The views expressed in this Working Paper are those of the author(s) and do not necessarily represent those of the IMF or IMF policy. Working Papers describe research in progress by the author(s) and are published to elicit comments and to further debate.
\end{abstract}

The paper investigates the determinants of foreign currency borrowing by the private sector in the new member states of the European Union. We find that striking differences in patterns of foreign currency borrowing between countries are explained by the loan-to-deposit ratios, openness, and the interest rate differential. Joining the EU appears to have played an important role, by providing direct access to foreign funding, offering hedging opportunities through greater openness, lending credibility to exchange rate regimes, and raising expectations of imminent euro adoption. The empirical evidence suggests that regulatory policies to slow foreign currency borrowing have had only limited success.

JEL Classification Numbers: E44, G21

Keywords: Foreign currency borrowing, new EU member states, Central and Eastern Europe Author’s E-Mail Address:crosenberg@imf.org, mtirpak@imf.org

\footnotetext{
${ }^{1}$ The authors would like to thank Ajai Chopra, Peter Backé, Zoltan Walko, Gavin Gray, Sònia Muñoz, Bikas Joshi, Albert Jaeger, Gustavo Canavire, Andrzej Raczko, Cezary Wójcik, and participants at a research seminar at the National Bank of Poland for their comments, and Agata Kariozen for excellent research assistance.
} 


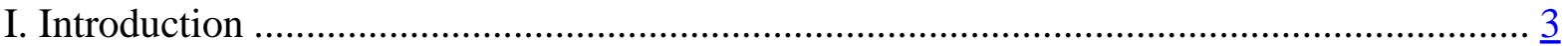

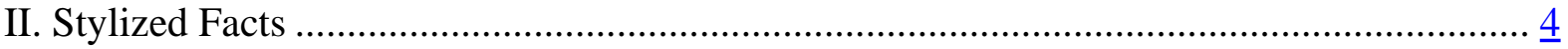

III. Reasons for Foreign Currency Borrowing —Some Hypotheses .................................. $\mathbb{7}$

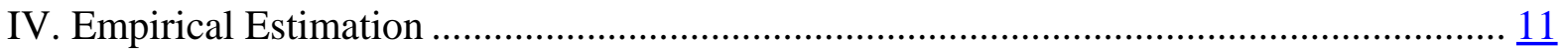

A. Model Structure and Data ............................................................................... $\frac{11}{13}$

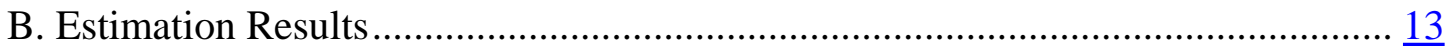

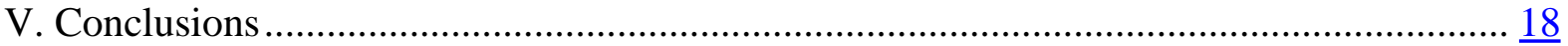

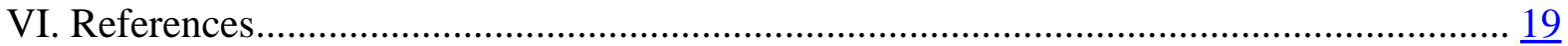

APPENDIX I. Data Sources and Transformations ............................................................ 21

APPENDIX II. Model Specification and Robustness Tests ........................................... $\underline{23}$ 


\section{INTRODUCTION}

Growing private sector borrowing in foreign currencies has become a familiar feature of the catching-up process in Central and Eastern Europe. This "dollarization"- in fact a “euroization" or "swissfrancization"- process", which appears closely linked to the rapid growth of private sector credit, has drawn warnings from the IMF and other observers ${ }^{3}$ regarding borrowers' vulnerability to sudden shifts in exchange rates. Some countries have taken regulatory measures to discourage foreign currency borrowing or have conducted monetary policy with an eye on the associated balance sheet risks.

Meanwhile, a full understanding of what drives foreign currency borrowing and what explains striking differences between countries in the region is still elusive. While there is agreement that the convergence-related demand for capital, largely satisfied by foreign parent banks, plays a key role, it is not fully clear how this interacts with a number of other factors such as individual countries' monetary policy, the effect of EU and ERM2 membership and regulatory policies. Only very recently has there been research examining these issues in the new member states of the EU (NMS).

This paper examines the drivers of foreign currency borrowing during the run-up to euro adoption using a multivariate approach. Specifically, we expand recent work by Basso, Calvo-Gonzales and Jurgilas (2007) and Brzoza-Brzezina, Chmielewski and Niedźwiedzińska (2007) by using a new dataset and some additional policy-related variables. Note that the paper does not examine credit growth in the NMS per se - a phenomenon that has been widely researched in recent years ${ }^{4}$ - but rather the change of composition in private sector credit from domestic to foreign currency.

The paper is organized as follows. Chapter II presents some stylized facts that highlight recent trends and differences among countries. Chapter III goes through some of the commonly offered hypotheses for foreign currency borrowing in the region. Chapter IV presents regression results from a model that includes a variety of variables and draws on a set of panel data for the NMS. Chapter V offers some tentative conclusions.

\footnotetext{
${ }^{2}$ Although somewhat of a misnomer, in line with the literature we use the term 'dollarization' to describe denomination or indexation of loans and deposits in currencies other than the domestic legal tender. In the region, the euro is the most commonly used foreign currency, but Swiss franc-denominated loans are also popular in some countries (e.g., Hungary, Poland).

${ }^{3}$ IMF (2007a), p. 90; IMF (2007b), p. 41; Bokor and Pellenyi (2005).

${ }^{4}$ See for example, Cottarelli, Dell’Ariccia and Vladkova-Hollar (2003); Kiss, Nagy and Vonnak (2006); Égert, Backé and Žumer (2006); Backé and Wójcik (2007).
} 


\section{STYLIZED FACTS}

\section{Rapid credit growth and a growing share of loans in foreign currency have become a} hallmark of the convergence process in many NMS. In the region, the ratio of the private sector's credit from banks to GDP has increased steeply over the last decade, with the share of loans denominated in or indexed to foreign currency increasing from 4 to 15 percent $^{5}$ (Figure 1). This trend appears to have accelerated over the last few years. While familiar in other emerging market regions, notably Latin America, dollarization is particularly strong in the NMS, suggesting that it is related to their accession to the EU (Figure 2).

Figure 1. NMS: Credit to the private sector (\% of GDP)

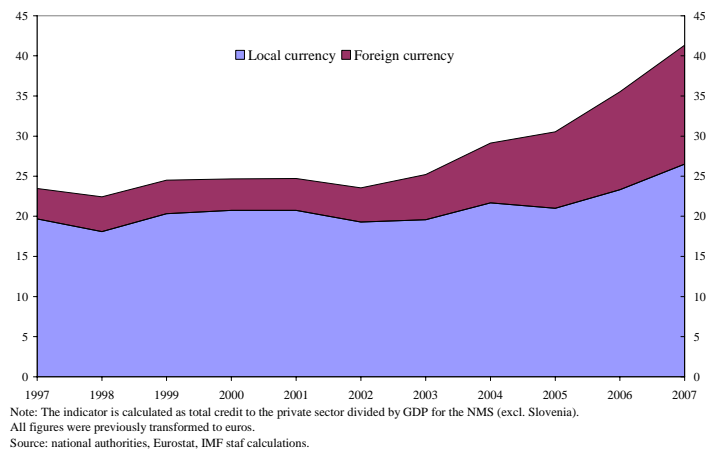

Figure 2. Emerging Markets: Foreign exchange borrowing (2005, as \% of total loans to the private sector)

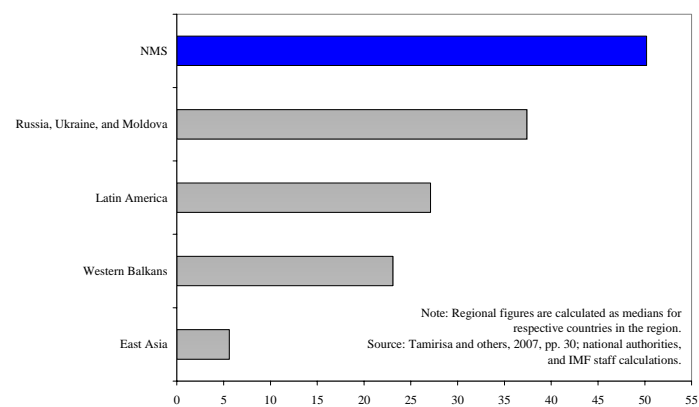

The dollarization process has been asymmetric between loans and deposits. While foreign currency borrowing expanded in many countries, foreign currency deposits remained broadly stable across the region ${ }^{6}$. In Figure 3 this can be seen by a shift of the gravity of financial dollarization away from the 45-degree line, indicating a growing exposure of private sector's balance sheets to currency risk. This trend is having potentially significant implications for the financial stability.

\footnotetext{
${ }^{5}$ Legal restrictions on foreign currency borrowing were lifted in most countries in the mid-1990s.

${ }^{6}$ This may suggest that demand side factors are increasingly playing a role in foreign exchnage borrowing, a point that is further investigated in sections 3 and 4 below.
} 
Figure 3. Financial dollarization in the NMS*
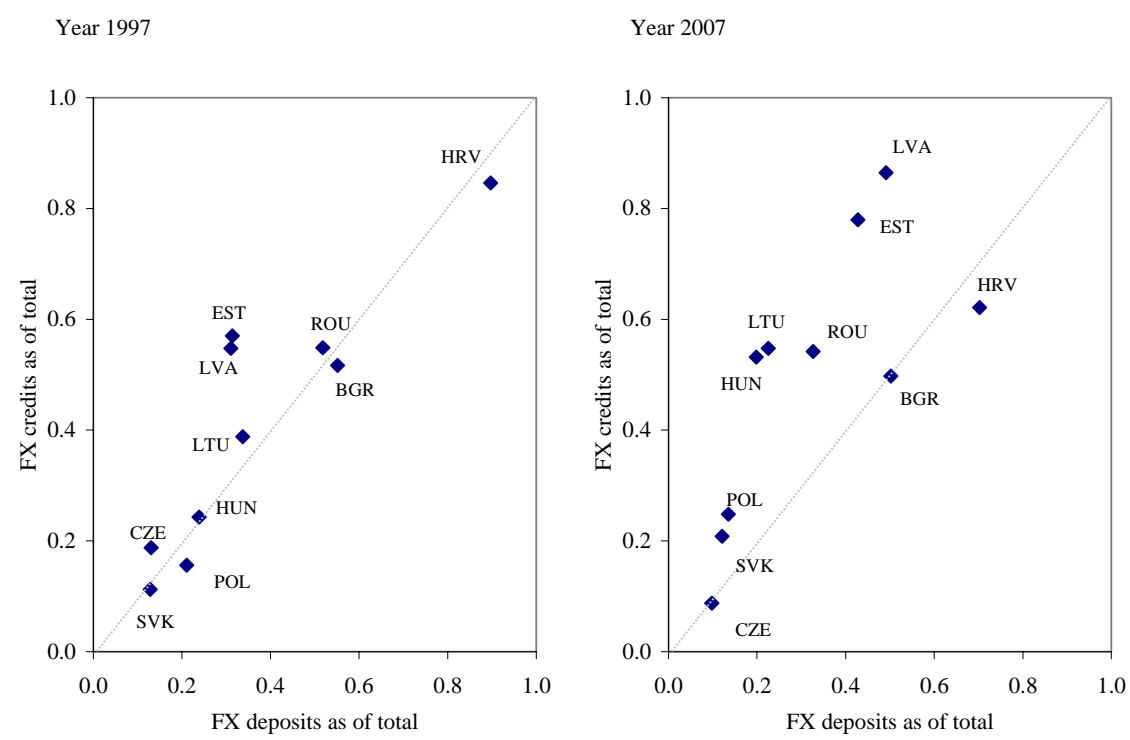

*Country sample: Bulgaria (BGR), Croatia (HRV), the Czech Republic (CZE), Estonia (EST), Hungary (HUN), Latvia (LVA), Lithuania (LTU), Poland (POL), Romania (ROU), and Slovakia (SVK).

Source: national authorities and IMF staff calculations.

There are striking differences between individual NMS. The composition of credit to the private sector is highly biased towards foreign currency in two Baltic countries--Estonia and Latvia (Group A in Figure 4)--while borrowers in Central Europe--the Czech Republic, Poland and Slovakia (Group B)-- prefer domestic currency.

There is an intermediate group of countries (Group C), where the share of local currency and foreign currency credits has remained roughly equal. Sometimes this phenomenon is explained by national characteristics (Czechs are supposedly more "conservative" than Estonians). The purpose of this paper is to investigate whether underlying these stereotypes are economic incentives and country-

Figure 4. Local currency vs foreign currency credit-to-GDP ratio (in \%, 2007)

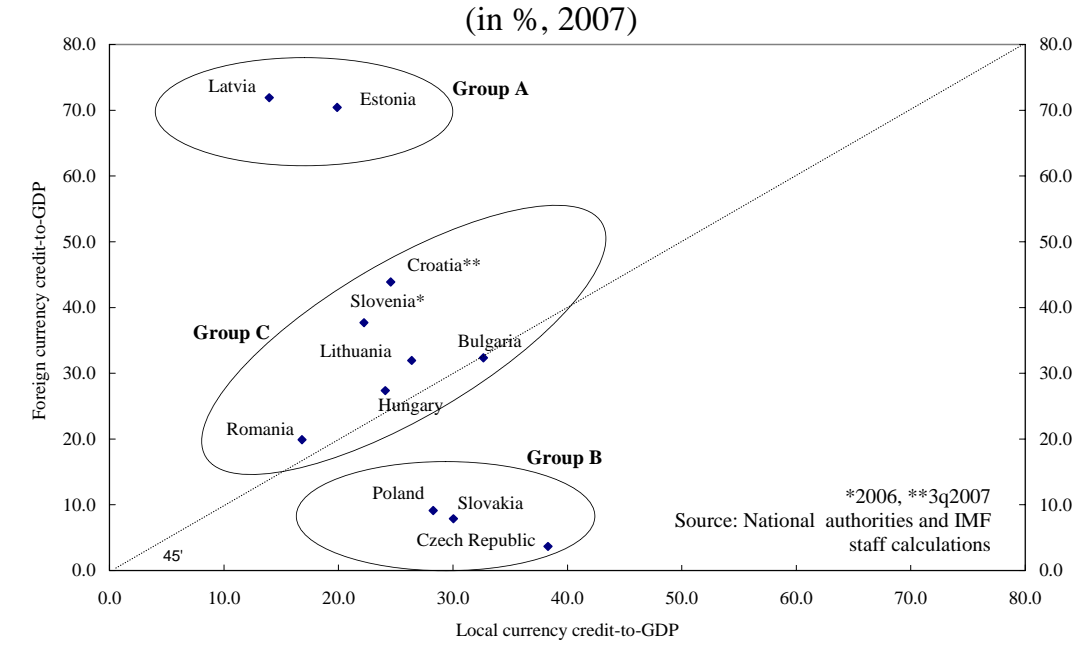
specific characteristics.

The dynamics and sectoral distribution of foreign-currency borrowing differ between NMS. In Figure 5, countries that saw an increase in the share of their foreign currency borrowing since the beginning of this decade are located to the North-East of the origin. The figure also highlights differences in borrowing behavior between households and non-financial corporations. If a country is positioned along the 45-degrees line, both sectors have increased 
their currency exposure at about the same rate. A location below the 45-degree line indicates that households have increased their currency exposure more than corporates. The dynamics of foreign exchange borrowing, as depicted in this figure, is affected by the initial share of foreign currency loans. Nevertheless, some country cases seem noteworthy.

- $\quad$ Households in Hungary increased the share of their foreign currency borrowing (+50 p.p.) more than in any other NMS, while non-financial corporations increased their foreign currency exposure only modestly (+10 p.p.).

- In Poland and Romania, on the other hand, households behaved opposite to nonfinancial corporations: they increased their share of loans denominated in foreign currency, while corporates slightly lowered their exposure.

- $\quad$ There are notable differences in borrowing behavior among the Baltic countries, a subregion that is often portrayed as homogenous. Latvia experienced strong growth in foreign currency borrowing, while in Estonia and Lithuania the increase was much less. In all three countries, however, households are more inclined to take on foreign currency exposure than corporates.

- $\quad$ Conversely, Bulgaria and Slovakia are the only two countries where corporates are more inclined to borrow in foreign currency than households. This may be related to their large inflows of foreign direct investment over the last years.

- $\quad$ The Czech Republic is the only country where there has been no increase in foreign currency borrowing at all.

Unfortunately, data limitations do not allow further examination of differences in borrowing behavior between households and non-financial corporations. The remainder of the paper will therefore focus on foreign currency borrowing by the private sector as a whole.

Figure 5. Foreign exchange loans as a share of total loans by sector

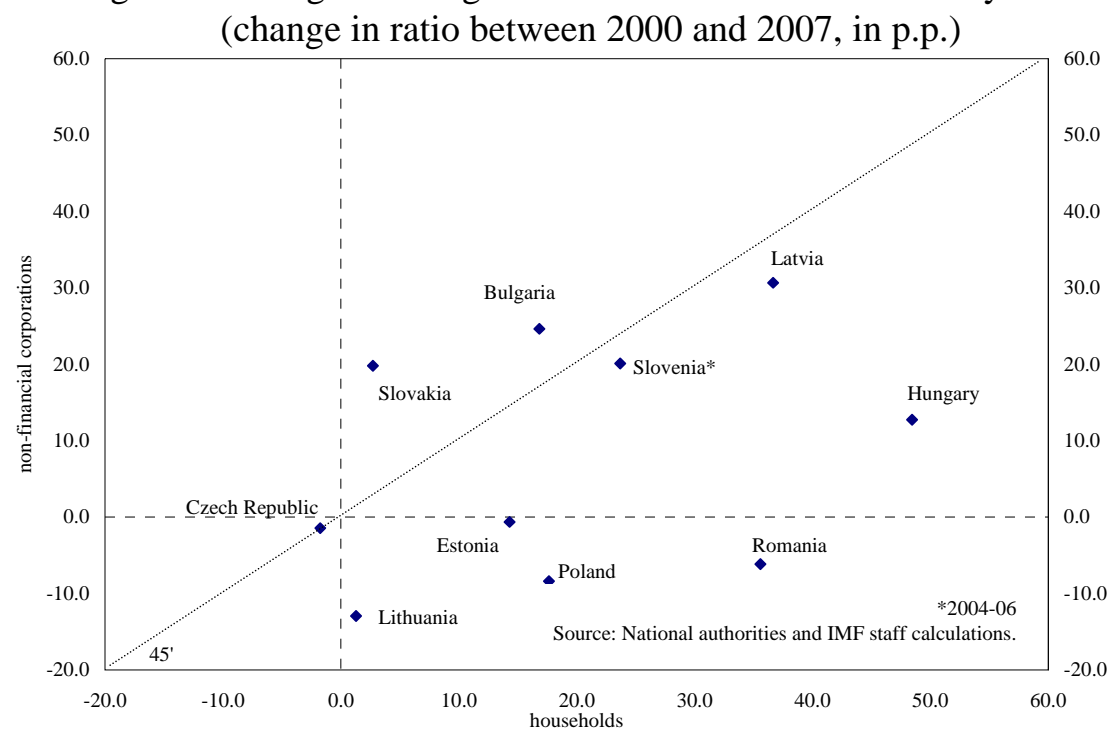




\section{REASONS FOR FOREIGN CURRENCY BORROWING-SOME HYPOTHESES}

Dollarization is not a new phenomenon. Borrowing in foreign currencies has been a common feature in many emerging market countries in Latin America and Asia. The "original sin" literature (Eichengreen and Hausmann, 1999), which developed following the financial crises of the late 1990s and originally focused on sovereign borrowing, attributed dollarization mostly to the lack of monetary policy credibility. But borrowing in foreign currencies has also been popular in the private sector and in some industrial countries in Europe, such as Italy and the Nordic countries in the early 1990s (Drees and Pazarbaşioğlu, 1998). The fact that dollarization led to painful balance sheet effects following sudden exchange rate depreciation has contributed to the view that it constitutes a vulnerability.

Overall credit growth and borrowing in foreign currencies are closely related. During transition, consumption smoothing is an important channel for credit expansion (Backé and Wójcik, 2007). Figure 6 illustrates that foreign currency borrowing has contributed to much of the overall credit growth, especially in countries where the private sector's indebtedness increased very rapidly in recent years.

Figure 6. Contribution to real credit growth (percent)
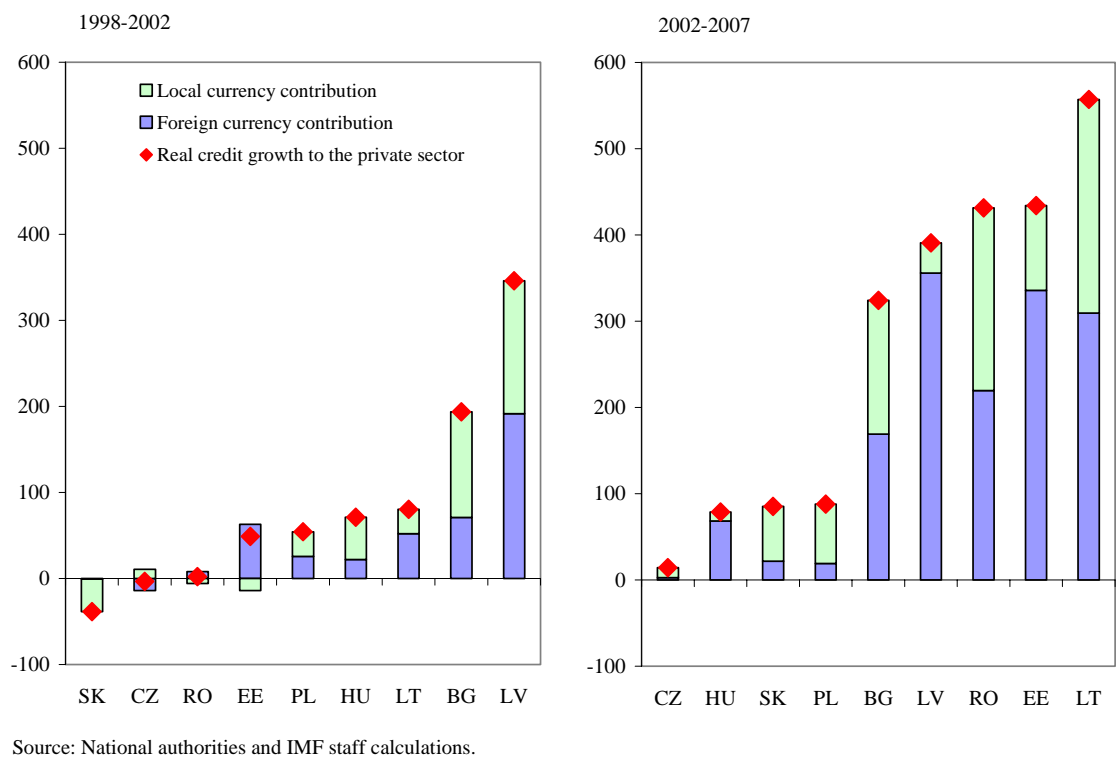

One reason for this may be that access to foreign currency loans, usually at lower rates than for domestic currency loans, not only affects the choice of currencies but also real interest rate as perceived by borrowers. When making a decision to borrow, they will often use expected domestic inflation or wage growth to deflate the nominal foreign currency interest rate, especially if they consider exchange rate risk to be low. As Figure 7 shows $^{7}$, this can yield highly negative real interest rates, thus greatly increasing the overall demand for credit. Since this paper is concerned with the currency composition of borrowing rather than overall credit growth, we will not pursue this linkage further.

\footnotetext{
${ }^{7}$ Expected inflation and wage growth is proxied by actual inflation and wage growth.
} 


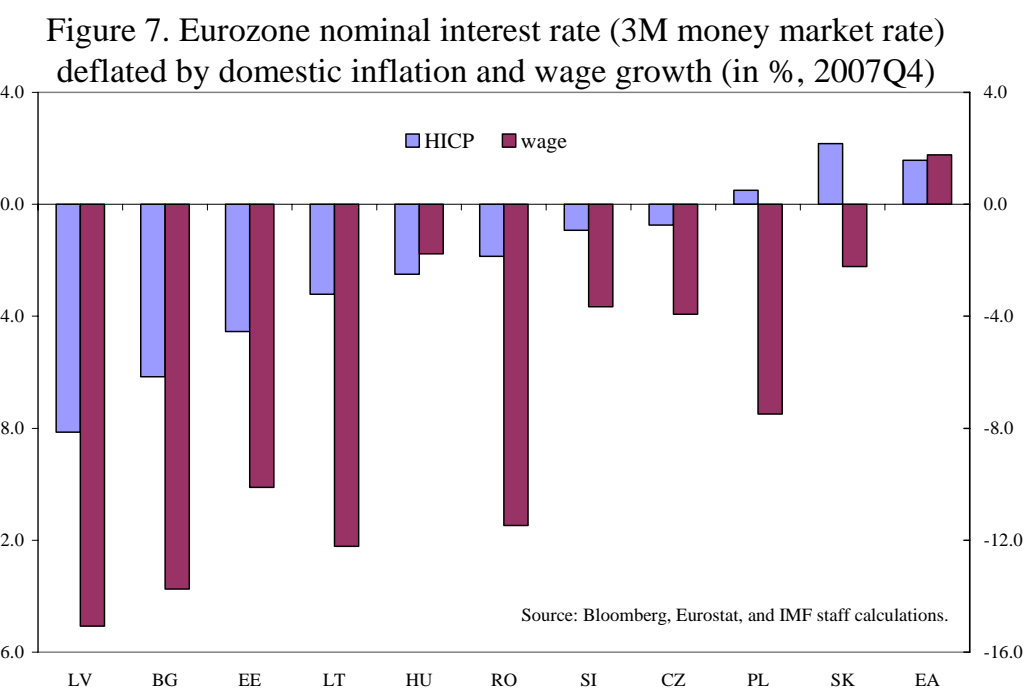

Interest rate differentials between local and foreign currency are believed to drive the choice between borrowing in domestic versus. foreign currency. Several recent empirical studies examining foreign currency borrowing in the NMS (Basso, Calvo-Gonzales and Jurgilas, 2007; Brown, Ongena and Yeşin, 2008) assume that uncovered interest rate parity does not necessarily hold and use nominal interest rate differences to explain dollarization. Figure 8 may at first glance seem counter-intuitive as it suggests that this difference is particularly large in countries where foreign-exchange borrowing has not been particularly high, such as Poland. Note, however that the significance of interest rate differentials depends on the credibility of the underlying currency regime and expectations regarding exchange rate movements and inflation

Figure 8. Interest rate* differential vis-à-vis euro (in p.p., nominal interest rates, average 4q1998 - 4q2007)

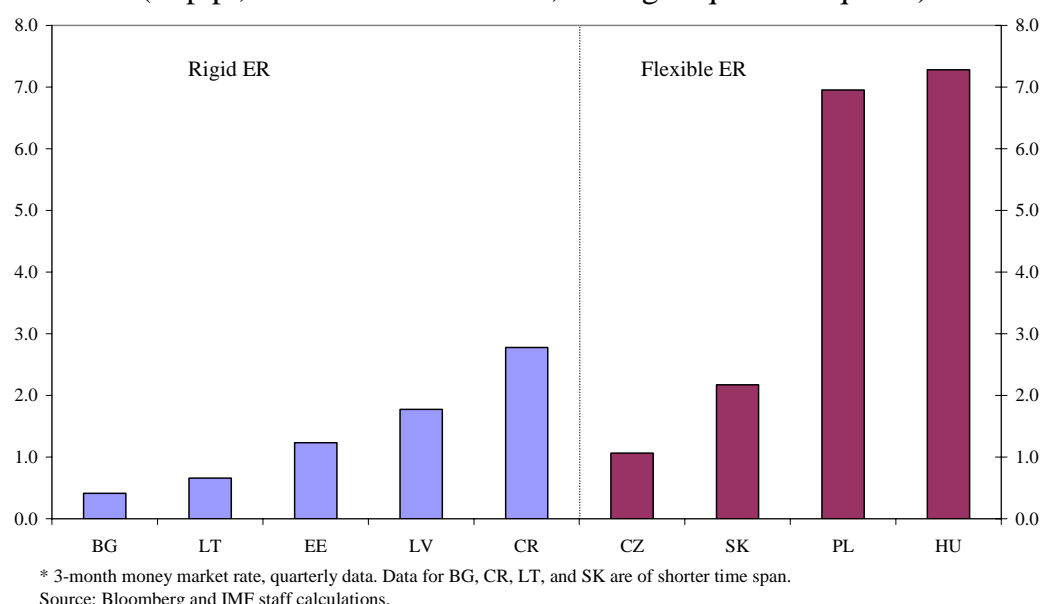
differentials. In a country with a highly credible peg, only a small interest rate differential can induce a shift in lending patterns, while in a flexible exchange rate regime a larger differential may be necessary to induce a similar shift. The rationale behind this is developed by Jeanne (2003), who built a theoretical model describing the determinants of liability dollarization from the perspective of borrowers.

At first glance, a country's currency regime appears to play a role as well. Backé and Wójcik (2007) suggest that perceived exchange rate risk is smaller in countries with exchange rate pegs, especially currency board regimes. This hypothesis seems to be confirmed by Figure 4 above: borrowers in countries with de facto rigid exchange rate regimes (Group A) are more 
willing to take foreign exchange risk than those with flexible exchange rate regimes (Group B). But the figure also highlights that the explanation cannot lie in the currency regime alone, as both Lithuania and Bulgaria have operated currency boards for many years, but have a much lower share of credit denominated in foreign currency. Moreover, a blunt classification into pegged and non-pegged exchange rate regimes is not warranted because in several cases (Latvia in 2005, Lithuania in 2002) the anchor currency was changed and in some other countries (Croatia, Hungary, Romania, and Slovenia) the exchange rate has been a de facto consideration in monetary policy making. When determining whether borrowers assess currency risk based on the expected stability of the exchange rate it would therefore seem useful to look at its actual past variability.

\section{The availability of foreign funds that are fueling the credit expansion in NMS may also}

Table 1. Asset share of foreign-owned banks (in \%)

\begin{tabular}{lcc}
\hline & 2000 & 2006 \\
\hline Estonia & 97.4 & 99.1 \\
Slovakia & 42.7 & 97.0 \\
Lithuania & 54.7 & 91.8 \\
Croatia & 84.1 & 90.8 \\
Romania & 46.7 & 87.9 \\
Czech Republic & 65.4 & 84.7 \\
Hungary & 67.4 & 82.9 \\
Bulgaria & 75.3 & 80.1 \\
Poland & 72.6 & 74.3 \\
Latvia & 74.4 & 62.9 \\
Slovenia & 15.3 & 29.5 \\
\hline Source: EBRD. & &
\end{tabular}

Figure 9. Loan-to-deposit ratio in the NMS

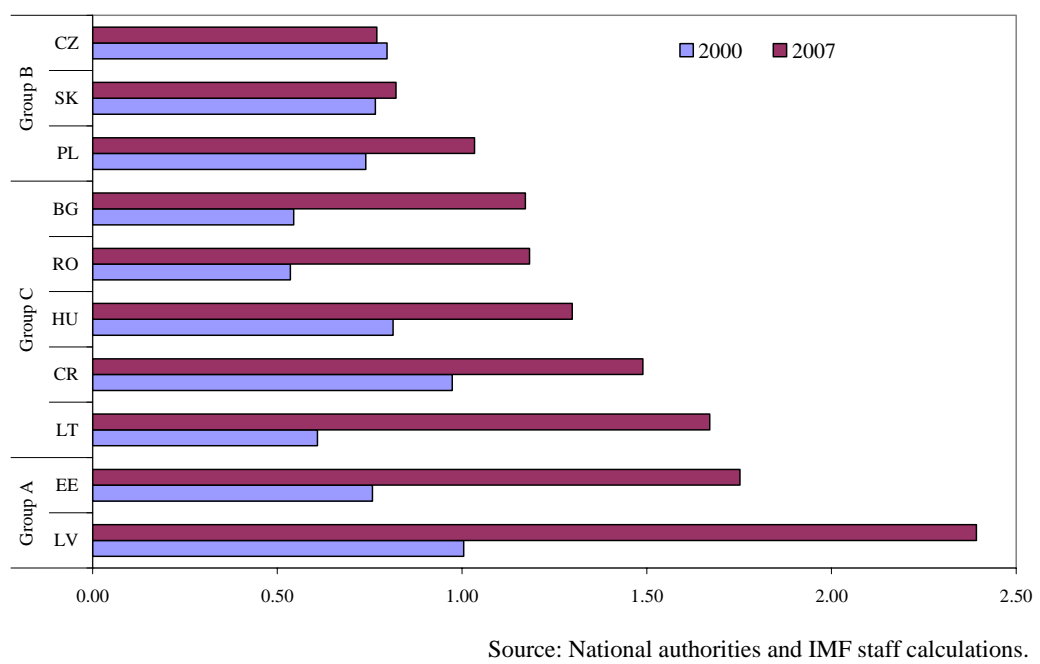
influence the currency composition of credit. As credit expands beyond the level of domestically available resources, banks attract capital from abroad. This is often done through existing financial links to parent banks residing in the EU. Since domestic bank regulations often restrict open currency positions, banks pass foreignfunded loans to their customers in foreign currency. This also allows them to transfer currency risk directly to borrowers (however, they still bear the credit risk). Apart from Slovenia, foreign-owned banks clearly dominate domestic banking sector in NMS and their presence has strengthened further during the last decade (Table 1, above). Figure 9 shows that countries experiencing a strong increase in loan-to-deposit ratio, driven by credit expansion (e.g., the Baltics), are also those borrowing in a foreign currency (from Figure 4 above). Basso, Calvo-Gonzales and Jurgilas (2007) develop a theoretical and empirical model that shows how the presence of foreign banks in the NMS increases liability dollarization.

Imminent euro adoption is expected to be a factor in financial dollarization, as for example suggested by Levy Yeyati (2006). One would expect borrowers to increase their borrowing in (cheaper) foreign currencies, if they think that currency risk will soon disappear. Foreign exchange borrowing did initially accelerate in the Baltics when they entered ERM2 - the 
Figure 10. NMS: Share of foreign exchange loans* and ERM 2 entry

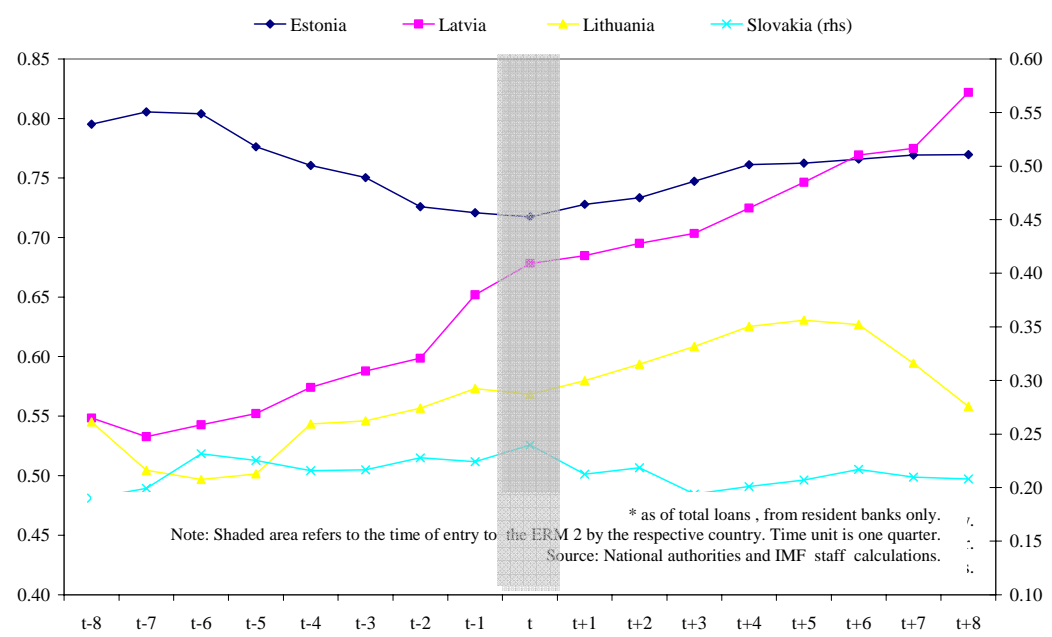

"antechamber to the euro"soon after joining the EU (Figure 10). In Slovenia the share of foreign currency loans to the private sector rapidly expanded during its successful run-up to the eurozone and a similar trend was observed earlier in Austria - although this may have also been related to the liberalization of rules regarding foreign currency borrowing at the time (Figure 11). In Slovakia, on the other hand, imminent euro adoption appears to have had no effect

on foreign currency borrowing. While the evidence is therefore mixed, events like EU membership and ERM 2 participation are usually thought to have some positive influence on the dollarization of credits in the NMS.

Figure 11. Share of the foreign exchange loans in the run-up to euro adoption (in \%)

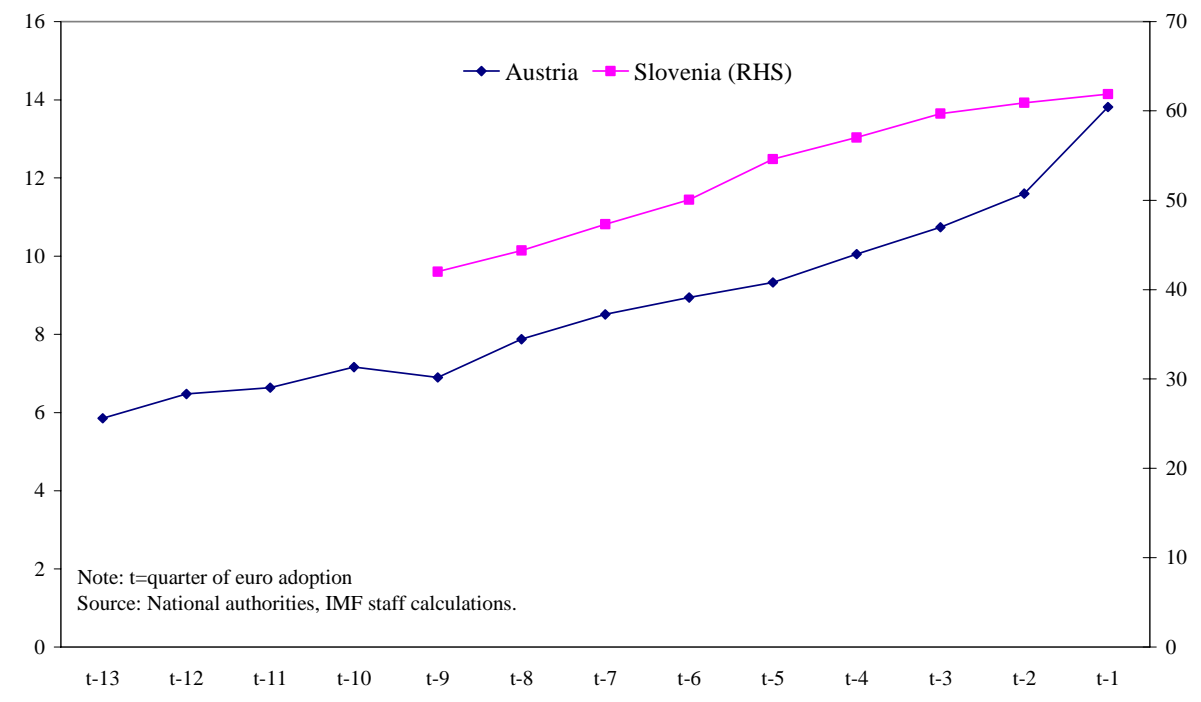

Finally, a country's economic policies surely have a bearing on foreign currency borrowing. The most obvious channel is through monetary policy which will directly affect the interest rate differential discussed above, as well as the volatility of the exchange rate. Taxes and subsidies can also influence borrowing behavior; for example, the tightening of eligibility criteria for housing subsidies in Hungary in 2004 is believed to have induced consumers to switch to cheap foreign currency loans (Bokor and Pellenyi, 2005). Conversely, recognizing risks associated with foreign currency loans, financial supervisors throughout the region have recently taken various regulatory measures to slow down such borrowing (Table 2). An interesting question, examined below, is whether these actions have had the intended effect. 
Table 2. Policies to discourage foreign currency borrowing

\begin{tabular}{|c|c|c|c|c|c|c|c|c|c|c|c|}
\hline & \multicolumn{11}{|c|}{ 2004Q4 } \\
\hline & $\mathrm{CZ}$ & EE & $\mathrm{HU}$ & LV & LT & PL & SK & SI & BG & RO & $\mathrm{CR}$ \\
\hline Monitor fx risk & $\mathrm{x}$ & & & $\mathrm{x}$ & & & & & & & \\
\hline \multicolumn{12}{|l|}{ Disclose fx risks to customers } \\
\hline \multicolumn{12}{|l|}{ Tighten eligibility criteria for $\mathrm{fx}$ borrowing } \\
\hline $\begin{array}{l}\text { Higher risk weights, provisioning, reserve } \\
\text { requirements depending on banks' fx exposure }\end{array}$ & & & & & & & & & & & $\mathrm{x}$ \\
\hline \multicolumn{12}{|l|}{ Ceiling on banks' fx exposure } \\
\hline & \multicolumn{11}{|c|}{ 2007Q4 } \\
\hline & $\mathrm{CZ}$ & $\mathrm{EE}$ & $\mathrm{HU}$ & LV & LT & PL & SK & SI & BG & RO & $\mathrm{CR}$ \\
\hline Monitor fx risk & $\mathrm{x}$ & & $\mathrm{x}$ & $\mathrm{x}$ & & & & & & $\mathrm{x}$ & $\mathrm{X}$ \\
\hline Disclose fx risks to customers & & & $\mathrm{x}$ & & & $\mathrm{X}$ & & & & & \\
\hline Tighten eligibility criteria for $\mathrm{fx}$ borrowing & & & & $\mathrm{X}$ & & $\mathrm{x}$ & & & & & \\
\hline $\begin{array}{l}\text { Higher risk weights, provisioning, reserve } \\
\text { requirements depending on banks' fx exposure }\end{array}$ & & & & $\mathrm{x}$ & & & & & & $\mathrm{x}$ & $\mathrm{X}$ \\
\hline Ceiling on banks' fx exposure & & & & & & & & & & & \\
\hline
\end{tabular}

IV. EMPIRICAL ESTIMATION

\section{A. Model Structure and Data}

The various hypotheses laid out above can be examined in a panel regression model (eq. 1). For the dependent variable we use the share of loans denominated in (and indexed to) foreign currency in total domestic bank loans to the non-financial private sector. An alternative specification of the dependent variable also includes the private sector's direct borrowing from abroad, all of which is assumed to be in foreign currency. ${ }^{8}$ Our preferred model contains the following key independent variables:

- the difference of nominal interest rates between local and foreign currency;

- the loan-to-deposit ratio to capture the degree to which funding for the non-financial private sector comes from abroad;

- the openness of the economy, and

\footnotetext{
${ }^{8}$ These loans are often granted to subsidiaries of foreign corporates operating in the NMS from banks that also provide financial services to their parent companies in the home country.
} 
- the severity of regulatory measures aimed at discouraging foreign currency borrowing.

Consequently, the model can be written as follows:

$$
\text { fxloans }_{i, t}=\alpha+\beta_{1} \text { irdiff }_{i, t}+\beta_{2} \text { loantodep }_{i, t}+\beta_{3} \text { openness }_{i, t}+\beta_{4} \text { restrict }_{i, t}+X_{i, t}+\varepsilon_{i, t}(1) \text {, }
$$

with the first four independent variables as described above and a vector $X_{i, t}$, consisting of a number of additional variables that were also tested but not included in the our preferred model (e.g., GDP per capita, asset share of foreign banks, size of the economy, EBRD index of banking sector reform, actual exchange rate volatility, and dummies for ERM2 and EU membership). The exact specification and empirical validity of all variables is discussed below.

The regression draws on quarterly data for the NMS. The sample of countries includes the new EU member states from Central and Eastern Europe that have not yet adopted the euro-the Czech Republic, Estonia, Hungary, Latvia, Lithuania, Poland, and Slovakia (which joined the EU in May 2004) ${ }^{9}$, Bulgaria and Romania (which joined in January 2007), as well as Croatia (EU candidate since 2004) ${ }^{10}$. We considered including a few non-NMS countries for which data were available (Portugal, Austria, Sweden, Denmark), but in the end decided to not pursue these because conditions in their preparatory phase for euro adoption were in important respects different from the NMS ${ }^{11}$. Hence, the panel includes 10 countries and quarterly data for the period 1999-2007. Data for loans and deposits in domestic and foreign currencies were derived from national sources, while most other data used for the independent variables were collected from Eurostat, IMF, EBRD and BIS databases. The index of policies to influence foreign exchange borrowing was constructed using information from IMF staff reports and a questionnaire among country desks. Data sources and transformations are described in Appendix I.

\section{The preferred model specification is estimated by OLS with country fixed effects and} appears robust. The relatively high correlation between our dependent variable and the loanto-deposit ratio suggested possible endogeneity problems, so we ran our baseline model with lagged loan-to-deposit ratio variables (up to 3 lags of the variable). In order to test for the robustness of the model, we included time dummies and also restricted our sample excluding outliers (Estonia, Latvia). In the latter specification the openness variable turned non-

\footnotetext{
${ }^{9}$ Slovenia was excluded because the available time series of data were much shorter than in the other countries. Data for Macedonia, another EU candidate country, were not compatible with those used for the other countries.

${ }^{10}$ Croatia represents an outlier, with much higher initial level of liability dollarization level than in the other countries.

${ }^{11}$ For example, in the old member states many restrictions on foreign currency borrowing were eliminated during the run-up to euro adoption, while many new member states had already abolished such restrictions by the end1990s, prior to their entry to the European Union.
} 
significant, otherwise the results were unaffected. Alternative specifications and robustness test are discussed in Appendix II.

\section{B. Estimation Results}

\section{As expected, the interest rate differential is an important driver of foreign currency}

borrowing. This variable ${ }^{12}$ has the expected positive sign and is highly significant (Table 3 , column A). In line with both the theoretical and the empirical literature, a higher interest rate differential leads to higher dollarization of liabilities in a country.

Table 3. Estimated coefficients from our preferred model

\begin{tabular}{|l|cc|}
\hline & Domestic banks only & Incl. cross-border loans \\
\hline Interest rate differential & $\mathrm{A}$ & $\mathrm{B}$ \\
Loan-to-deposit ratio & $0.00113^{\star \star \star}$ & $0.00179^{\star * \star}$ \\
Openness & $0.17037^{\star * *}$ & $0.07032^{\star *}$ \\
FX restriction index (lagged) & 0.07414 & $0.12138^{\star *}$ \\
& $-0.02467^{\star * *}$ & $-0.01377^{\star *}$ \\
\hline
\end{tabular}

Note: $* ; * * * * * *$ refers to significance at $10 \%, 5 \%, 1 \%$ level respectively.

For a discussion on the model specification, see Appendix II. Time dummies are included.

Source: Authors' calculations.

The correlation can be nicely traced in Lithuania (Figure 12), where the share of foreign currency denominated new mortgages declined in 2005-06, when the interest rate differential shrank from some 150 basis points to around zero; but the process reversed when the difference subsequently increased again. In our model, an increase of the interest rate differential by 100 basis points would increase the share of foreign exchange loans by some $0.1-0.2$ percentage points. This effect may appear small compared to the example shown in Figure 12. Recall, however, that our dependent

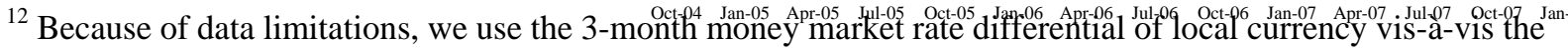
Figure 12. Lithuania: Share of foreign currency loans (in EUR) on housing loans and interest rate differential

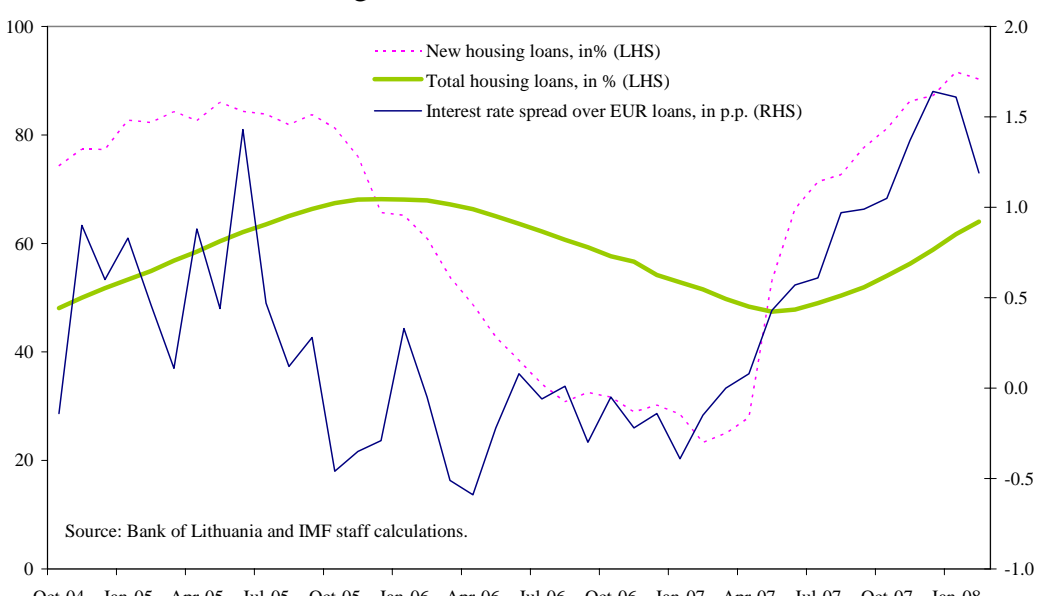
euro $\left(i-i^{*}\right)$. While this ignores the fact that in some countries foreign currency loans are often denominated in Swiss franc, these interest rates are highly correlated with Euro interest rates (factor 0.96). Using this approximation also implies that risk premium and fees for the median borrower in a country are constant in one point in time for both local currency loans and foreign currency loans. Anecdotal evidence confirms that, at least until recently, banks did not include the currency risk in their calculations. 
variable is defined as a stock variable covering all private sector loans.

The loan-to-deposit ratio is also highly significant and has the expected sign. (Table 3 , column A). This suggests that as countries during convergence draw on capital inflows to fund domestic borrowing for consumption smoothing purposes, they tend to rely relatively more on foreign currency loans. Unlike Basso, Calvo-Gonzales and Jurgilas (2007), we find that it is irrelevant whether such foreign funding is channeled through domestic banks borrowing abroad (e.g., through syndicated loans) or foreign-owned banks drawing on credit lines from their parent banks. In our model, the share of foreign banks in total assets is not significant and is highly correlated with openness. Indeed, it is not entirely obvious why foreign-owned banks should be biased towards extending loans in foreign currencies ${ }^{13}$. Note that in our model the loan-to-deposit ratio also acts as a proxy for financial openness and liberalization and it is positively correlated with the EBRD's index of banking sector reform. As one would expect, the coefficient is smaller in the model specification that includes direct borrowing from abroad as the dependent variable (Table 3, column B).

NMS with large catch-up potential tend to prefer foreign currency borrowing. This can be seen in a model specification that uses random country effects and introduces per capita income in 1998 as a share of the EU25 average as a an additional independent variable (Appendix II). This variable, which is akin to a country dummy ${ }^{14}$, also proxies the overall state of economic development and is, not surprisingly, positively correlated with the EBRD's index of banking sector reform ${ }^{15}$.

Country size matters. We found that smaller countries are generally more prone to choose foreign currency loans, maybe because the upfront cost of developing domestic currency instruments are harder to justify. Modelling size by GDP as of the EU average increases the overall fit of the model but interacts strongly with other potential determinants of foreign currency borrowing, such as the currency regime (smaller countries tend to prefer pegs), openness (in smaller countries trade and remittances are a larger share in GDP), and GDP per capita (smaller countries are relatively poorer). The same is true when modelling country size by various measures of population. Due to these multilcollinearity problems, we decided to exclude country size from our preferred model specification.

\footnotetext{
${ }^{13}$ On the one hand, foreign banks until recently found it easy to raise funds at Euribor and onlend these to their local subsidiaries, giving them a stronger competitive position in foreign currency lending than local banks. On the other hand, some foreign banks (e.g. from Italy and the US) are known to be biased against foreign currency lending to households because of bad past experience (for Italian banks after the 1992 ERM crisis and for US banks after the 2002 collapse of the Argentinian currency board). This is not the case, however, for Austrian, Swedish and German banks which dominate lending in many countries.

${ }^{14}$ This variable also tracks quite well the initial level of liability dollarization, which is in line with the findings from the literature (see for example, Levy Yeyati, 2006). Relatively poorer countries tend to have more dollarized balance sheets.

${ }^{15}$ In an alternative specification, adding the EBRD's index as an additional variable yields the expected sign and is highly significant, but due to very high correlation with the openness variable we were forced to exclude it from our model.
} 
The effect of past exchange rate volatility on dollarization is ambiguous in our model. Figure 13 shows that there appears to be a negative relationship between the volatility of the exchange rate ${ }^{16}$ and the share of foreign exchange loans. This correlation has increased in recent years. The panel regression found, however, that past exchange rate volatility does not appear to play much of a role when correcting for other factors: while the coefficient has the expected sign, it is very small and not statistically significant. ${ }^{17}$ This contrasts with empirical findings from other regions (e.g., Kamil, 2007, for Latin American

Figure 13. Exchange rate volatility and foreign currency loans

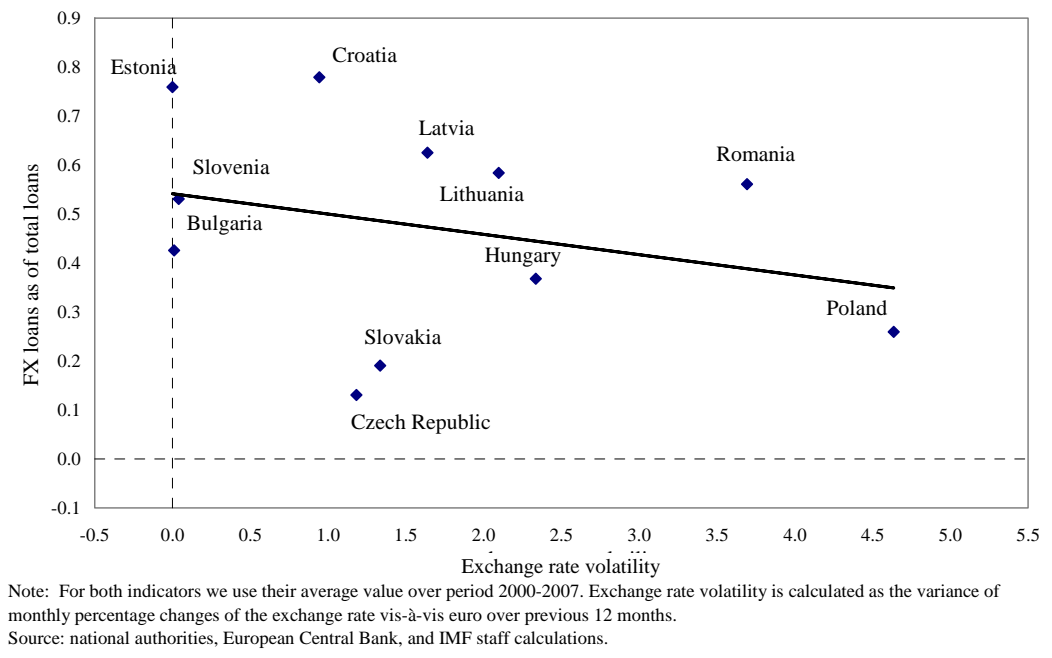
corporates) which suggest the opposite. Why do East Europeans behave differently? One possibility is that our study does not fully capture uncertainties surrounding the exchange rate regime, for example by neglecting inflation expectations. Indeed, Basso, Calvo-Gonzales and Jurgilas (2007) find that the trade-off between inflation and real exchange rate variability can be a factor explaining financial dollarization ${ }^{18}$, although they acknowledge the methodological difficulties leading to this result. An economic explanation may be that EU membership is increasing economic agents' confidence in the stability of the exchange rate, making them more willing to assume currency risk. Moreover, nominal exchange rates have been generally appreciating in countries with flexible currency regimes, making borrowing in foreign currencies even more attractive. ${ }^{19}$

\footnotetext{
${ }^{16}$ Defined as the variance of monthly percentage changes of exchange rate vis-à-vis the euro over the previous 12 months.

${ }^{17}$ Modelling the exchange rate impact by using not actual past volatility but a dummy that distinguishes between fixed and flexible regimes yields a significant coefficient, but suffers from the shortcomings discussed in the section III above, i.e., it is too imprecise and may capture other factors such as country size and geography (Baltics).

${ }^{18}$ In an alternative specification, we used minimum variance portfolio (a formula combining variance of inflation and real exchange rate and their covariances, popularized by Ize and Levy Yeyati, 2003) as an explanatory variable. Like others (Basso, Calvo-Gonzales and Jurgilas , 2007) we found that the results are extremely sensitive to the time window covered by the variable. In addition, its statistical significance is weak in our model specification.

${ }^{19}$ We were not able to test this hypothesis because data on expected exchange rates (from Reuters polls) were only available for a few countries. Brzoza-Brzezina, Chmielewski and Niedźwiedzińska (2007) find that the level of exchange rates matters: borrowers take foreign exchange loans when the domestic currency is strengthening.
} 
Joining the European Union does not have any discernable direct effect on foreign currency borrowing. A dummy variable for EU membership has the expected sign, but was not statistically significant. The reason may be that the associated confidence effects come into play before the actual entry date and at different times in different countries, something that is difficult to measure. Another way to test both the expected time until euro adoption ${ }^{20}$ and expectations about exchange rate stability is participation in the Exchange Rate Mechanism (ERM2), which ex ante limits exchange rate movements, especially the scope for large depreciations. Again, this dummy variable is not statistically significant. The explanatory power of ERM2 may be affected by the fact that the majority of countries participating in it (i.e., the Baltics) joined with an already rigid exchange rate regime.

Hedging opportunities in the private sector increase dollarization, at least in the corporate sector. We use various measures of openness - exports plus imports, exports of goods and nonfactor services - which all have the correct positive sign, however, their statistical significance varies across different specifications. Revenues from abroad make it easier for corporates to hedge their foreign currency exposure. This does not, however, seem to be the case for households, as remittances have a negative sign. Our preferred specification uses the sum of exports and imports as a measure for openness (Table 3, column A).

Finally, regulatory policies aimed at reducing foreign currency borrowing may have only limited effect. Based on the information provided in Table 2 above, we construct an index measuring the severity of such measures, ranging from stepped-up monitoring (least restrictive) to quantitative limits on foreign currency lending of banks ${ }^{21}$ (most restrictive) ${ }^{22}$. To guard against reverse causality, the model uses various lags for this variable. Policies against foreign currency lending have the expected sign in a specification that uses only borrowing from domestic banks as the dependent variable (Table 3, column A), but the statistical significance is reduced when direct borrowing from abroad is included as well and the coefficient for the index halves (Table 3, column B). This illustrates that various measures imposed by domestic financial supervisors indeed affect the flow of foreign currency credit through the domestic banking system, but may also divert borrowing to non-resident financial institutions. With no capital account restrictions in the NMS, such policies may therefore be largely ineffective.

Our model tracks well actual developments in most countries (Figure 14). This is particularly the case for Central European countries and Bulgaria. In Hungary and Latvia, two

\footnotetext{
${ }^{20}$ We tried to capture the effect of expected euro adoption more directly by using data from the Reuters poll on expected entry dates. Unfortunately, the short time span of the time series does not allow for meaningful statistical analysis.

${ }^{21}$ Such a measure was in the past in place in Romania.

${ }^{22}$ The index is defined as: Index $i, t=\sum$ policy, $_{i, t}$. The value of the index is calculated as follows: monitoring FX risk -- 0.2, disclosure of FX risk to customers -- 0.4, tightening of eligibility criteria for FX borrowing -- 0.6, higher FX risk weights/provisioning/reserve requirement -- 0.8, and introduction of ceilings on FX exposure -- 1.0. Only measures that strictly targeted foreign exchange borrowing (as opposed to overall credit growth) were considered.
} 
countries that have recently seen a very rapid rise on foreign exchange borrowing, the actual share of foreign currency loans started to deviate from the predicted value around 2005, suggesting that some additional factors are at work. Similarly, in Croatia the recent decline of foreign exchange borrowing is not fully captured by the model.

Figure 14. Actual and predicted ratio of FX loans on total loans in the NMS
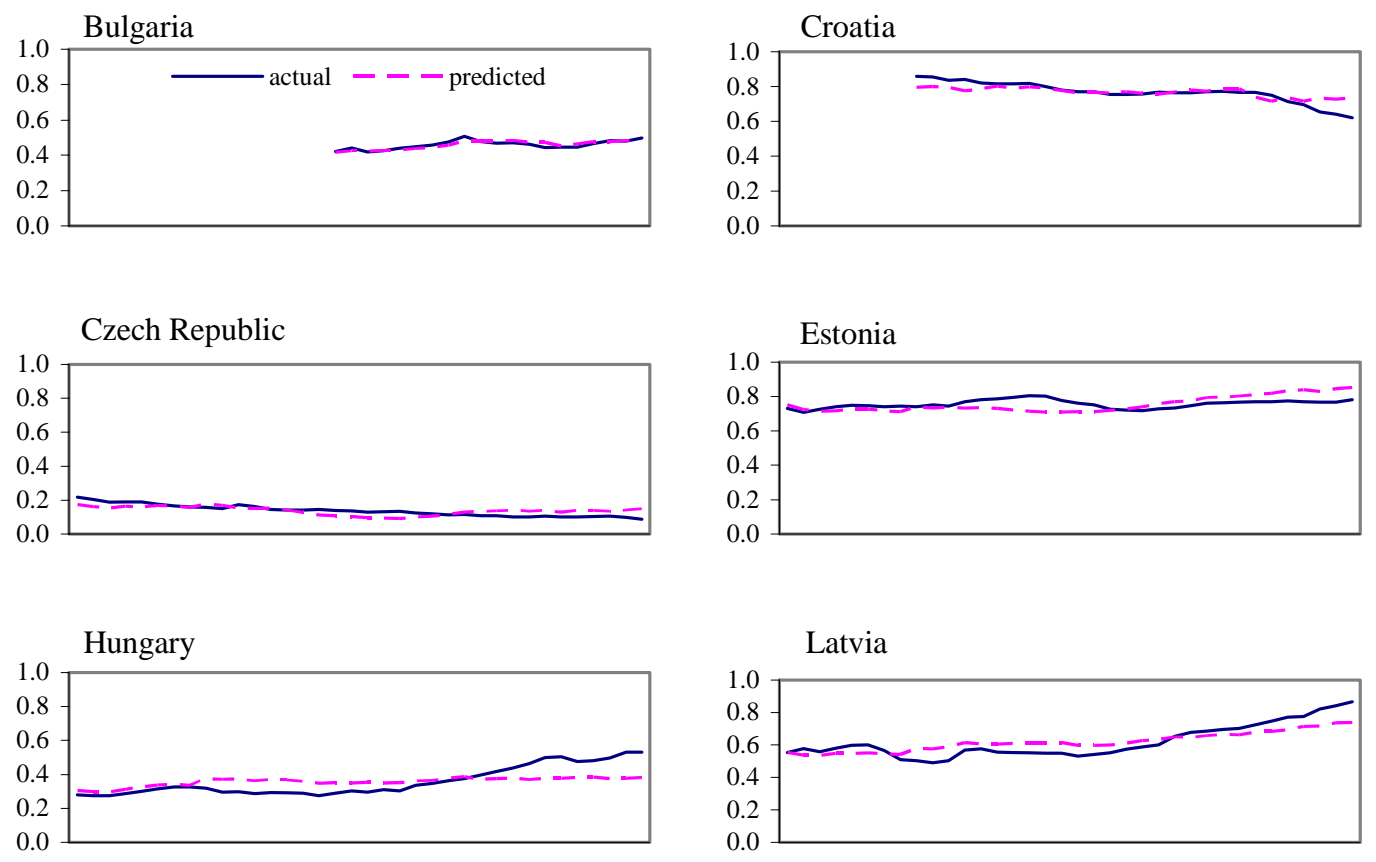

Latvia
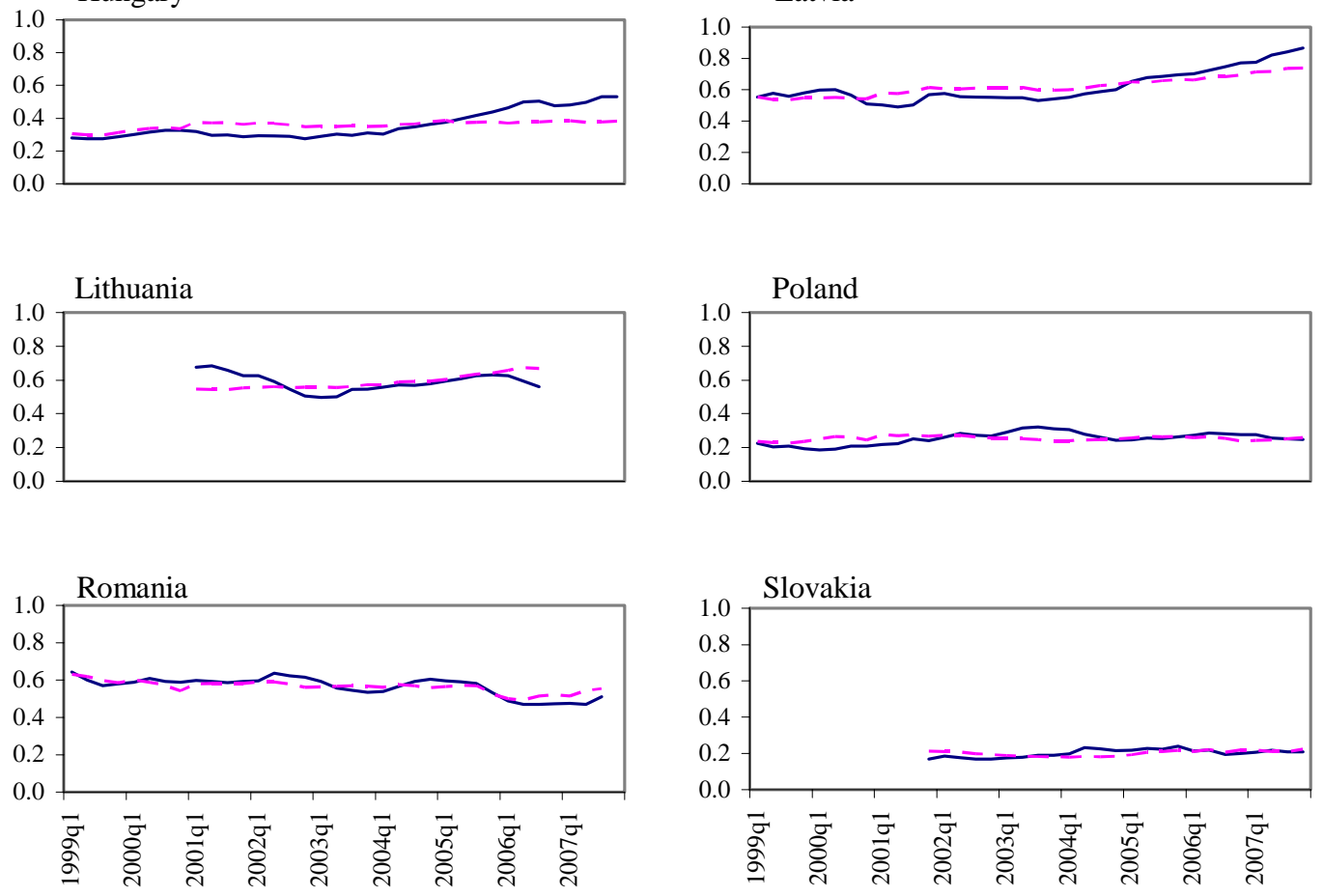

Source: National authorities and IMF staff calculations. 


\section{CONCLUSIONS}

We found that growing dollarization of liabilities in the NMS can be primarily explained by the interest rate differential and the extent to which credit is funded from abroad. Dollarization can be seen as a byproduct of convergence-a process that is necessarily characterized by capital inflows driven by higher rates of return in the recipient countries. A number of other measurable variables, such as country size, income level, trade openness and regulatory policies have a bearing on foreign currency borrowing by the private sector. Our model, which draws on panel data for NMS from Central and Eastern Europe plus Croatia and covers the period 1999-2007 is robust to alternative specifications.

The central point from this analysis is that membership in the European Union boosts foreign currency borrowing through various indirect channels. First, by fully liberalizing the capital account, EU membership offers borrowers increased access to foreign funding, both through domestic banks affiliated with foreign parents and directly from abroad. Secondly, by increasing trade openness, it provides hedging opportunities, especially for the corporate sector. Finally, EU membership appears to boost the private sector's confidence in exchange rate stability and imminent euro adoption. As a result, borrowers appear to consider a devaluation a low-probability event and therefore neglect the exchange rate risk associated with borrowing in foreign currency. This is further enforced by existing interest rate differentials. For the same reasons, commercial banks appear to also be more willing to extend loans in foreign currency.

\section{In this environment, policy options to guard against the risks associated with foreign} currency borrowing are limited. There are concerns that the private sector may err in its assessment of currency risk, maybe because it puts undue faith in EU or ERM2 membership. The empirical analysis shows, however, that regulatory measures aimed at slowing foreign currency borrowing are largely ineffective because access to foreign financing directly from abroad makes it easy to circumvent them. Given that under EU law capital account restrictions are not an option to close this loophole, any measures to address foreign currency exposures will require close cooperation between supervisors in home and host countries. Also, a further increase in trade openness would be helpful as it increases hedging opportunities for the private sector. Of course, this both encourages access to foreign capital (and the associated foreign currency borrowing) and makes it safer. More generally, macroeconomic policies aimed at increasing national savings would reduce the need to rely on foreign funding. Finally, eventual euro adoption would eliminate currency risk. 


\section{REFERENCES}

Backé, Peter and Cezary Wójcik, 2007, “Credit Booms, Monetary Integration and the New Neoclassical Synthesis”, Journal of Banking \& Finance 32 (2008), pp. 458-470.

Basso, Henrique S., Oscar Calvo-Gonzales, and Marius Jurgilas, 2007, "Financial Dollarization: The Role of Banks and Interest Rates”, ECB Working Paper No 748, European Central Bank, May 2007.

Bokor László and Gábor Pellenyi, 2005, “Foreign Currency Denominated Borrowing in Central Europe: Trends, Factors, and Consequences”, ICEG EC Opinion V., February 2005.

Brzoza-Brzezina, Michał, Tomasz Chmielewski, and Joanna Niedźwiedzińska, 2007, "Substitution Between Domestic and Foreign Currency Loans in Central Europe. Do Central Banks Matter?”, National Bank of Poland conference; November 2007, http://www.nbp.pl/Konferencje/NBP Nov2007/Speakers/Brzoza-Brzezina.pdf

Brown, Martin, Steven Ongena, and Pinar Yeşin, 2008, “Currency Denomination of Bank Loans: Evidence from Small Firms in Transition Countries”, CentER Discussion Paper No. 16, Tilburg University, February 2008.

Cottarelli, Carlo, Giovanni Dell’Ariccia, and Ivanna Vladkova-Hollar, 2003, “Early Birds, Late Risers, and Sleeping Beauties: Bank Credit Growth to the Private Sector in Central and Eastern Europe and the Balkans”, IMF Working Paper 213, International Monetary Fund, November 2003.

Drees, Burkhard and Ceyla Pazarbaşioğlu, 1998, The Nordic Banking Crises: Pitfalls in Financial Liberalization?, IMF Occasional Paper 161, International Monetary Fund, April 1998.

Égert, Balázs, Peter Backé and Tina Žumer, 2006, “Credit Growth in Central and Eastern Europe: New (Over)shooting stars?”, ECB Working Paper No 687, European Central Bank, October 2006.

Eichengreen, Barry, and Ricardo Hausmann, 1999, “Exchange Rates and Financial Fragility”, NBER Working Paper 7418, November 1999.

International Monetary Fund, 2007a, “Globalization and Inequality”, World Economic Outlook, October 2007.

International Monetary Fund, 2007b, “Strengthening Financial Systems”, Regional Economic Outlook Europe, November 2007.

Ize, Alain, and Eduardo Levy Yeyati, 2003, Financial dollarization, Journal of International Economics 59 (2003), pp. 323-347. 
Jeanne, Olivier, 2003, “Why Do Emerging Market Economies Borrow in Foreign Currency?”, IMF Working Paper No. 177, International Monetary Fund, September 2003.

Kamil, Herman, 2008, "Does moving to a flexible exchange rate regime reduce currency mismatches in firms' balance sheets?", IMF Working Paper (forthcoming).

Kiss, Gergely, Márton Nagy, and Balázs Vonnak, 2006, “Credit Growth in Central and Eastern Europe: Trend, Cycle or Boom?”, Magyar Nemzeti Bank, http://english.mnb.hu/Engine.aspx?page=mnben seminar\&ContentID=7919

Levy Yeyati, Eduardo, 2006, "Financial dollarization: Evaluating the consequences”, Economic Policy, Vol. 21, No. 45, pp. 61-118.

Tamirisa, Natalia, Douglas Laxton, Andy Jobst, Gavin Gray, Thomas Harjes, and Emil Stavrev, 2007, “The Euro and the New Member States”, Euro Area Policies: Selected Issues, International Monetary Fund, July 2007. 


\section{APPENDIX I. Data Sources and Transformations}

Appendix Table 1. Description and transformation of variables

\begin{tabular}{|c|c|c|}
\hline Variable & Source & Description \\
\hline Share of foreign loans & $\begin{array}{l}\text { National authorities and own } \\
\text { calculations }\end{array}$ & $\begin{array}{l}\text { The variable is calculated as the sum of loans to the private sector (i.e., households and non-financial corporations) denominated in foreign curency to total loans to the private } \\
\text { sector (i.e., households and non-financial corporations) denominated in both, local currency and foreign currency. }\end{array}$ \\
\hline $\begin{array}{l}\text { Share of foreign loans } \\
\text { (incl. cross-border loans) }\end{array}$ & $\begin{array}{l}\text { National authorities, Joint } \\
\text { External Debt Hub, IFS, and } \\
\text { own calculations }\end{array}$ & $\begin{array}{l}\text { We adjust the share of foreign loans in total loans by adding cross-border loans to non-bank sector from the Joint External Debt Hub, assuming that these loans are all } \\
\text { denominated in foreign currency. Raw data are transformed to local currency using quarterly exchange rates from IFS. The data on cross-border loans cover the entire non-bank } \\
\text { private sector, while our domestic credit data cover only the non-financial private sector (i.e., non-bank financial institutions are not covered). However, non-bank financial } \\
\text { corporations account for less than } 10 \% \text { of total credit granted by domestic banking sector (Hungary is an exception with } 12.2 \% \text { share in 4q2007) and the pattern of currency } \\
\text { denomination of credits mimics the one of non-financial private sector agents. }\end{array}$ \\
\hline Credit to private sector & $\begin{array}{l}\text { National authorities (central } \\
\text { banks) }\end{array}$ & $\begin{array}{l}\text { Credit to the private sector disaggregated by currency (i.e., local currency and foreign exchange) and credit to households and to non-financial corporations. In local currency } \\
\text { units. }\end{array}$ \\
\hline Interest rate differential & $\begin{array}{l}\text { Bloomberg and own } \\
\text { calculations }\end{array}$ & $\begin{array}{l}\text { Raw data (daily frequency) are transformed into 12-month moving averages. The interest rate differential is calculated as the difference between interbank interest rate (3-month } \\
\text { money market rate) for a respective country and the corresponding euro rate }\left(\text { i.e., } i-i^{*}\right) \text {. Unit is a percentage point. }\end{array}$ \\
\hline Loan-to-deposit ratio & Own calculations & Calculated from the data on credits and deposits of the non-financial private sector as the sum of credits divided by the sum of deposits. \\
\hline Credit-to-GDP ratio & Own calculations & Calculated from the data on credits of the non-financial private sector from national authorities and GDP from IFS. \\
\hline GDP per capita in year 1998 & Eurostat & GDP per capita in PPS as of EU25 in year 1998 \\
\hline Exchange rate volatility & ECB and own calculations & $\begin{array}{l}\text { Using monthly exchange rates vis-à-vis the euro from the ECB database, we calculate the volatility as the variance of monthly percentage changes of the exchange rate vis-à-vis } \\
\text { the euro over the previous } 12 \text {-months. }\end{array}$ \\
\hline FX restrictions index & Own calculations & Index based on information collected from the IMF staff reports for respective countries. For further details please see page 15 (footnote 22). \\
\hline Openness & IFS and own calculations & 4-quarter moving average of the sum of imports and exports (goods \& non-factor services) as a share of GDP in current prices. All data are from IFS. \\
\hline Remittances & $\begin{array}{l}\text { IFS, World Bank, and own } \\
\text { calcuations }\end{array}$ & $\begin{array}{l}\text { 4-quarter moving average of the sum of compensation of employeess, workers' remittances and migrants' transfers divided by GDP in current prices from IFS. Alternatively, we } \\
\text { use World Bank's remittance database (available at http://go.worldbank.org/QOWEWD6TA0) and GDP in current prices from IFS. The remittances dummy assumes the value of } \\
1 \text {, when the value of remittances (as of GDP) is higher than } 75 \text { percentile of the variable over the sample, and zero otherwise. }\end{array}$ \\
\hline EU entry dummy & European Commission & $\begin{array}{l}\text { The binary variable takes the value of } 1 \text { from } 2 \text { q2004 onwards for EU8 countries (i.e., the Czech Republic, Estonia, Hungary, Latvia, Lithuania, Poland, Slovakia and Slovenia), } \\
\text { and zero otherwise. For Bulgaria and Romania the EU entry dummy takes value of } 1 \text { from } 1 \text { q2007 onwards and zero otherwise. For Croatia the variable takes the value of zero } \\
\text { over the whole time sample. }\end{array}$ \\
\hline ERM II entry dummy & European Commission & $\begin{array}{l}\text { The binary variables takes value of } 1 \text { from } 392004 \text { for Estonia, Lithuania and Slovenia onwards; from } 2 q 2005 \text { for Latvia onwards; from } 4 \mathrm{q} 2005 \text { for Slovakia onwards, and zero } \\
\text { otherwise. For all remaining countries (i.e., Bulgaria, the Czech Republic, Croatia, Hungary, Poland, Romania) the variable takes the value of zero over the whole time period. }\end{array}$ \\
\hline ER regime dummy & IMF & $\begin{array}{l}\text { The variable takes the value of } 1 \text { if a country has a flexible exchange rate regime, and zero otherwise. For the construction of this variables we used various issues of IMF's } \\
\text { Classification of Exchange Rate Arrangements and Monetary Frameworks. }\end{array}$ \\
\hline GDP in PPS; Population & Eurostat & Various specifications, e.g., GDP total as a percentage of total EU25 GDP (in PPS), Population as of the eurozone population, etc. \\
\hline Minimum variance portfolio & IFS and own calculations & $\begin{array}{l}\text { Calculation based on Ize and Levy Yeyati (2003). The monthly series of annual HICP inflation are used (except for Croatia where CPI index is used) and monthly series of the } \\
\text { real exchange rate are calculated vis-à-vis the euro. We use various moving windows (12-month, 24-months) and also all historical data available to calculate the MVP. }\end{array}$ \\
\hline EBRD index of banking sector reform & EBRD & The same value of the index is used for all quarters in a respective year. \\
\hline Asset share of foreign-owned banks & EBRD & Since data are on an annual basis, linear interpolation and fixed values for all quarters in a respective year are used. \\
\hline
\end{tabular}


Appendix Table 2. Summary statistics

\begin{tabular}{|c|c|c|c|c|c|}
\hline Variable & Observations & Mean & Std. Dev. & Min & Max \\
\hline Asset share of foreign-owned banks & 359 & 0.710 & 0.2245 & 0.030 & 0.994 \\
\hline Credit-to-GDP & 398 & 0.318 & 0.1654 & 0.087 & 0.901 \\
\hline EBRD banking sector reform index & 440 & 3.413 & 0.4556 & 2.300 & 4.000 \\
\hline Exchange rate volatility & 318 & 1.883 & 2.3588 & 0.0 & 11.971 \\
\hline Export-to-GDP & 433 & 0.535 & 0.1620 & 0.222 & 0.879 \\
\hline FX restrictions index & 430 & 0.220 & 0.6333 & 0.0 & 4.200 \\
\hline GDP in PPS as \% of total EU25 GDP & 436 & 1.052 & 1.0932 & 0.100 & 4.300 \\
\hline GDP per cap. in PPS in year 1998 as of EU25 avg. & 440 & 0.421 & 0.1187 & 0.250 & 0.670 \\
\hline Int. rate diff vs EUR, in p.p. & 318 & 5.873 & 12.1978 & -1.290 & 81.368 \\
\hline Loan-to-deposit ratio & 429 & 0.911 & 0.3152 & 0.373 & 2.435 \\
\hline Openness-to-GDP & 433 & 1.134 & 0.3135 & 0.465 & 1.792 \\
\hline Population as of total eurozone population & 440 & 0.034 & 0.0353 & 0.004 & 0.129 \\
\hline Remittances-to-GDP (IFS) & 399 & 0.016 & 0.0193 & 0.0 & 0.119 \\
\hline Remittances-to-GDP (WB) & 440 & 0.014 & 0.0166 & 0.0 & 0.086 \\
\hline Share of FX loans & 429 & 0.452 & 0.2252 & 0.088 & 0.923 \\
\hline Share of FX loans (incl. cross-border loans) & 419 & 0.543 & 0.1961 & 0.202 & 0.939 \\
\hline
\end{tabular}

Source: Authors' calculations. 


\section{APPENDIX II. Model Specification and Robustness Tests}

The preferred model is estimated with OLS using country fixed effects. Appendix Table 3 shows pooled OLS regression, fixed-effect and random effect models. While the random-effects model estimation has a better overall fit (as measured by a higher adjusted $\mathrm{R}^{2}$ ), there appears to be some correlation between estimated unobservable effects and explanatory variables. The fixed-effects model may therefore be preferable as it allows to control for time-constant heterogeneity in the country sample. The preference of fixedeffect model was also confirmed by performing the Hausman test. We use robust standard errors to correct for possible heteroskedasticity in the data.

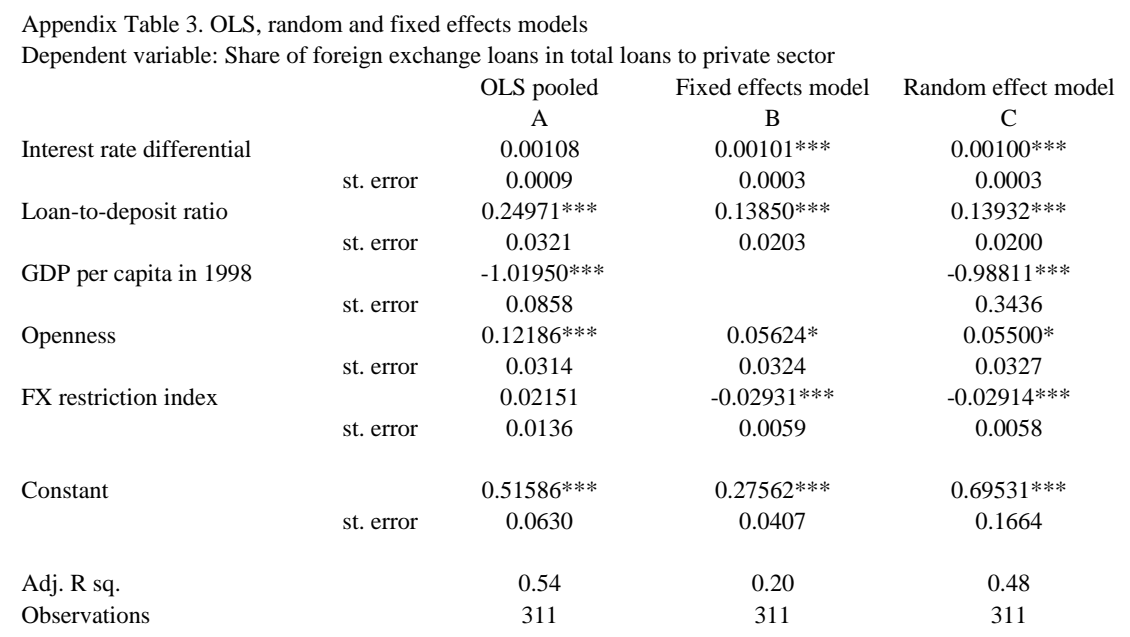

Note: $* ; * ; * * *$ refers to significance at $10 \%, 5 \%$, and $1 \%$ level respectively. Heteroscedasticity-robust standard errors are shown.

Source: Authors' calculations.

In order to test for the robustness of the model, we include time dummies and also used country sample excluding outliers (i.e., Estonia and Latvia). These control for common shocks to countries during the observation period. The results are not changed qualitatively. However, the significance level for the FX restriction index is somewhat reduced (Appendix Table 4).

\begin{tabular}{|c|c|c|c|c|c|}
\hline & & $\begin{array}{c}\text { OLS pooled } \\
\text { A }\end{array}$ & $\begin{array}{l}\text { Fixed effects model } \\
\text { B }\end{array}$ & $\begin{array}{l}\text { FE with time dummies } \\
\text { B. } 1\end{array}$ & $\begin{array}{l}\text { excl. EE \& LV } \\
\text { B. } 2\end{array}$ \\
\hline \multirow[t]{2}{*}{ Interest rate differential } & & 0.00108 & $0.00101 * * *$ & $0.00113^{* * *}$ & $0.00089 * * *$ \\
\hline & st. error & 0.0009 & 0.0003 & 0.0003 & 0.0003 \\
\hline \multirow[t]{2}{*}{ Loan-to-deposit ratio } & & $0.24971^{* * *}$ & $0.13850^{* * *}$ & $0.17037 * * *$ & $0.13087 * * *$ \\
\hline & st. error & $\begin{array}{c}0.0321 \\
-1.01950^{* * *}\end{array}$ & 0.0203 & 0.0278 & 0.0367 \\
\hline GDP per capita in 1998 & st. error & 0.0858 & & & \\
\hline \multirow[t]{2}{*}{ Openness } & & $0.12186^{* * *}$ & $0.05624 *$ & 0.07414 & -0.08565 \\
\hline & st. error & 0.0314 & 0.0324 & 0.0630 & 0.0810 \\
\hline \multirow[t]{2}{*}{ FX restriction index } & & 0.02151 & $-0.02931 * * *$ & $-0.02467 * * *$ & $-0.04427 * * *$ \\
\hline & st. error & 0.0136 & 0.0059 & 0.0069 & 0.0068 \\
\hline \multirow[t]{2}{*}{ Constant } & & $0.51586 * * *$ & $0.27562 * * *$ & $0.20373^{*}$ & $0.37548 * * *$ \\
\hline & st. error & 0.0630 & 0.0407 & 0.1071 & 0.1096 \\
\hline Adj. R sq. & & 0.54 & 0.20 & 0.27 & 0.20 \\
\hline Observations & & 311 & 311 & 311 & 239 \\
\hline
\end{tabular}

Note: *; **; ** refers to significance at $10 \%, 5 \%$, and $1 \%$ level respectively. Heteroscedasticity-robust standard errors are shown. Source: Authors' calculations. 
Using the loan-to-deposit ratio as an explanatory variable in our model may entails an endogeneity problem. Due to lack of efficient instrumental variables, we use the lagged loan-to-deposit ratio to test for signs of endogeneity. As shown in Appendix Table 5 , the previous results hold when using the loan-to-deposit ratio lagged by one quarter. The same is true when using longer lags.

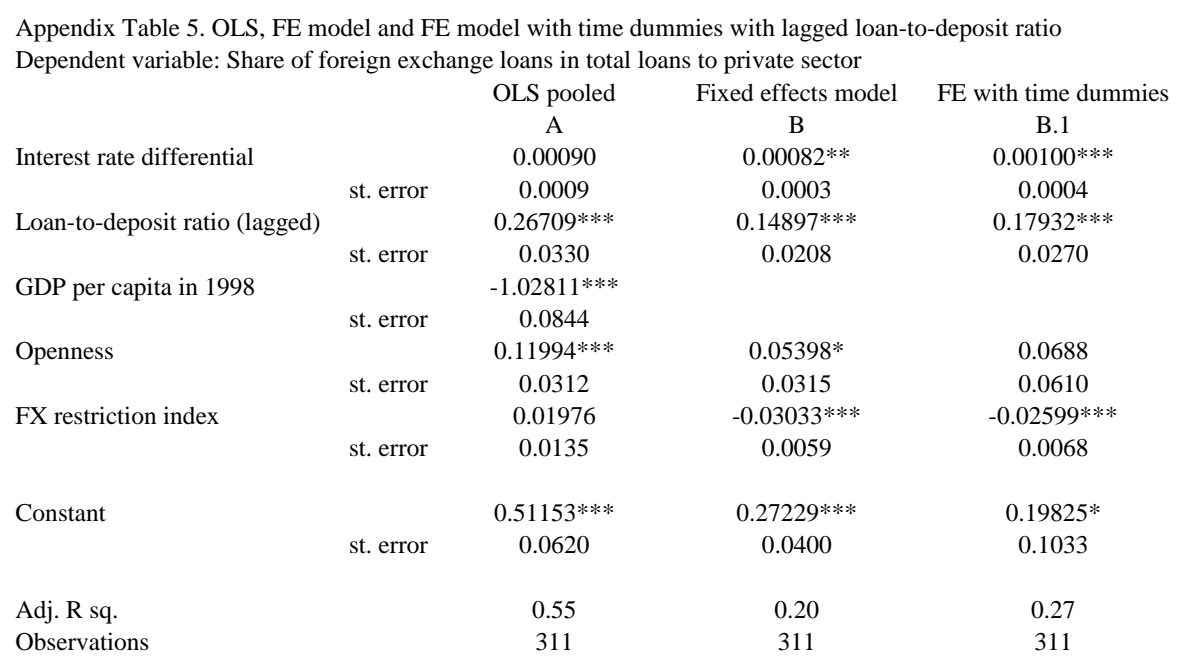

Note: *; **; *** refers to significance at $10 \%, 5 \%$, and $1 \%$ level respectively. Heteroscedasticity-robust standard errors are shown. 